\title{
Combined effect of limestone fine aggregate and pozzolan on properties of high performance fine-grained concrete
}

\author{
Lam Tang Van ${ }^{1,2, *}$, Dien Vu Kim ${ }^{1}$, Hung Ngo Xuan ${ }^{1,2}$, Doan Tung Lam Nguyen ${ }^{1}$, Boris \\ Bulgakov ${ }^{1}$ and Sophia Bazhenova ${ }^{1}$ \\ ${ }^{1}$ Moscow State University of Civil Engineering, Yaroslavskoe Shosse, 26, Moscow, 129337, Russia \\ ${ }^{2}$ Hanoi University of Mining and Geology, 18 Pho Yen, Duc Thang, Bac Tu Liem, Hanoi, Vietnam
}

\begin{abstract}
This paper used the absolute volume method combined with the experiment to determine the compositions of high performance finegrained concrete (HPFC) and presented the effect of limestone fine aggregate (LFA) and pozzolan (PU) on the HPFC properties. Test results showed that by increasing the LFA and PU, the workability of the concrete mixture decreased, the maximum slump loss after 90 minutes of mixing was $37.84 \%$, whereas the mechanical properties of HPFC increased. The fine-grained concrete mixture containing $40 \%$ PU and LFA completely replaced material for natural sand, the compressive strength of concrete at 28-day increased about $23.87 \%$ in comparison to the control mixture. By using the standard NT Build 356, the destruction time of the four specimens tested was of $45,63,60$ and 61 days, respectively. This result is due to the presence of PU increased the volume of the C-S-H, as well as the density of concrete structure and enhanced the strength of HPFC, thus increased destruction time of specimens used for the assessment of corrosion damage of reinforced in the concrete. The results of the current study support the use of the waste limestone from the quarries as a fine aggregate of green concrete in the future.
\end{abstract}

\section{Introduction}

The natural raw materials are used in the production of heavy concrete and mortar poses the problem of acute shortage in many countries including Vietnam. The results of published researches [1-3] indicated that many industrial, agricultural and quarry wastes were used as a substitution for these raw materials in the mixtures.

As it is known, in technology concrete, limestone is popularly used as coarse and fine aggregate in concrete because of its high reserve. The effect of limestone coarse aggregate on concrete properties has been examined by some previous researchers and the advantages of using limestone as raw materials in concrete were proved [4-6].

Particularly, in the studies [7, 8] were investigated the properties of concrete using crushed limestone sand replacing natural sand. Their results indicated that concrete using

\footnotetext{
* Corresponding author: lamvantang@gmail.com
} 
crushed sand with superplasticizer had good mechanical properties. Additionally, both water demand and cement paste amount of the limestone fine aggregate (LFA) concrete were higher than that used in normal sand concrete. In addition, these researches were reported that concrete made with limestone had a higher mechanical than the conventional concrete containing natural fine aggregate. Furthermore, the study of Chang et al. [9] showed that LFA concrete had a better acid resistance than siliceous aggregate concrete, especially when it was used complying with silica fume and fly ash. Recently, in order to improve the properties of limestone aggregate concrete and mortar, fly ash, marble powder, and silica fume were utilized as supplementary materials [10-12].

High performance fine-grained concrete (HPFC) appeared in recent years, and other new types of concrete ushered in the era of a new generation of buildings and structures: skyscrapers of reinforced concrete of various architectural forms, underground mini-cities, concrete platforms for oil and gas extraction on the ocean shelves and many other responsible structures operating in harsh $[2,13,14]$. Therefore, the using many wastes of industries replacing natural materials in high performance fine-grained concrete is greatly important to obtain new types of environmentally-friendly concrete in the future.

The main objective of present investigation is to study the possibility of recycling waste limestone sourced from quarries "Kien Khe" (Vietnam) as a fine aggregate and the use of natural pozzolan replacing $(20 \div 40) \%$ of cement in fine-grained concrete. Moreover, the applying the standard NT Build 356 for assessment of the degree of protection against corrosion's reinforced in the concrete specimen is also investigated in this study.

\section{Research programs}

\subsection{Materials properties}

1. The Portland cement (PC) is used SEM I 42.5 N, which manufactured at "But Son" factory (Vietnam) with the specific weight of $3.15 \mathrm{~g} / \mathrm{cm}^{3}$. Table 1 are presented the mineralogical compositions and mechanical properties of this Portland cement.

Table 1. Mineralogical compositions and characteristics of Portland cement "But Son".

\begin{tabular}{|c|c|c|c|c|c|c|c|c|c|c|}
\hline \multicolumn{3}{|c|}{ Mineral composition (wt. \%) } & \multirow{2}{*}{$\begin{array}{c}\text { Surface area } \\
\left(\mathrm{cm}^{2} / \mathrm{g}\right)\end{array}$} & $\begin{array}{c}\text { Soundness - } \\
\text { Lechatelier } \\
(\mathrm{mm})\end{array}$ & \multicolumn{2}{|c|}{$\begin{array}{c}\text { Time of setting } \\
(\mathrm{min})\end{array}$} & \multicolumn{2}{|c|}{$\begin{array}{c}\text { Compressive } \\
\text { strength (MPa) }\end{array}$} \\
\cline { 1 - 5 } $\mathrm{C}_{3} \mathrm{~S}$ & $\mathrm{C}_{2} \mathrm{~S}$ & $\mathrm{C}_{3} \mathrm{~A}$ & $\mathrm{C}_{4} \mathrm{AF}$ & Other & & Initial & Final & 3 days & 28 days \\
\hline 55.1 & 27.2 & 5.1 & 11.3 & 1.3 & 3420 & 1.5 & 142 & 245 & 33.5 & 51.4 \\
\hline
\end{tabular}

2. Natural pozzolan (PU) with the specific weight of $2.82 \mathrm{~g} / \mathrm{cm}^{3}$, the volume of natural state of $980 \mathrm{~kg} / \mathrm{m}^{3}$ and water demand of $28.5 \%$. Retained content of PU on sieve $0.09 \mathrm{~mm}$ is $10.5 \%$. In this case of the work, PU and PC were used as a binder materials.

3. Quartz sand (QS) sourced original from "Lo river" in the North of Vietnam was used as fine aggregate in concrete mixtures.

4. Limestone fine aggregate (LFA) sourced original from quarry "Kien Khe" (Vietnam) be crushed finely and was used as a QS substitution in mixes of this study. In Table 2 are given the physical properties of both QS and LFA.

Table 2. The physical properties of quartz sand and limestone fine aggregate.

\begin{tabular}{|c|c|c|c|c|c|c|}
\hline $\begin{array}{c}\text { Aggregate } \\
\text { type }\end{array}$ & $\begin{array}{c}\text { Aggregate } \\
\text { size }(\mathrm{mm})\end{array}$ & $\begin{array}{c}\text { Loose density } \\
\left(\mathrm{kg} / \mathrm{m}^{3}\right)\end{array}$ & $\begin{array}{c}\text { Dry density } \\
\left(\mathrm{g} / \mathrm{cm}^{3}\right)\end{array}$ & $\begin{array}{c}\text { Saturated density } \\
\left(\mathrm{kg} / \mathrm{m}^{3}\right)\end{array}$ & $\begin{array}{c}\text { Water absorption } \\
(\%)\end{array}$ & $\begin{array}{c}\text { Fineness } \\
\text { modulus }\end{array}$ \\
\hline QS & $0.15 \div 5$ & 1450 & 2.65 & 1620 & 0.50 & 3.1 \\
\hline LFA & $0.15 \div 5$ & 1420 & 2.66 & 1650 & 0.50 & 2.95 \\
\hline
\end{tabular}

The analysis results of chemical compositions of both PC, PU and LFA are presented in Table 3. In addition, the raw material particle size distribution is shown in Figure 1. 
Table 3. The chemical properties of PC, PU and LFA.

\begin{tabular}{|c|c|c|c|c|c|c|c|c|c|c|c|}
\hline \multirow{2}{*}{$\begin{array}{c}\text { Material } \\
\text { type }\end{array}$} & \multicolumn{10}{|c|}{ Compositions (wt. \%) } \\
\cline { 2 - 13 } & $\mathrm{SiO}_{2}$ & $\mathrm{Al}_{2} \mathrm{O}_{3}$ & $\mathrm{Fe}_{2} \mathrm{O}_{3}$ & $\mathrm{SO}_{3}$ & $\mathrm{~K}_{2} \mathrm{O}$ & $\mathrm{Na} 2 \mathrm{O}$ & $\mathrm{MgO}$ & $\mathrm{CaO}$ & $\mathrm{CO}_{2}$ & $\mathrm{P}_{2} \mathrm{O}_{5}$ & Loss on ignition \\
\hline $\mathrm{PC}$ & 18.6 & 4.5 & 3.1 & 3.1 & 0.6 & 0.2 & 3.2 & 63.6 & - & 0.9 & 2.2 \\
\hline $\mathrm{PU}$ & 49.8 & 22.1 & 12.6 & 1.5 & 1.2 & 1.3 & 4.6 & 3.6 & - & - & 3.3 \\
\hline LFA & 6.01 & 0.465 & 0.202 & - & - & 0.13 & 0.523 & 54.9 & 37.6 & 0.17 & - \\
\hline
\end{tabular}

5. SR-5000F superplasticizer (SP) "SilkRoad" (Hanoi-Korea co., Ltd., Vietnam) with a specific gravity of $1.1 \mathrm{~g} / \mathrm{cm}^{3}$ at $25^{\circ} \mathrm{C}$ was used to reduce the water-to-cement ratio and achieve the desired workability of concrete mixtures.

6. Local clean water $(\mathrm{W})$ is used throughout this work for both making concrete mixes and curing of tested specimens.

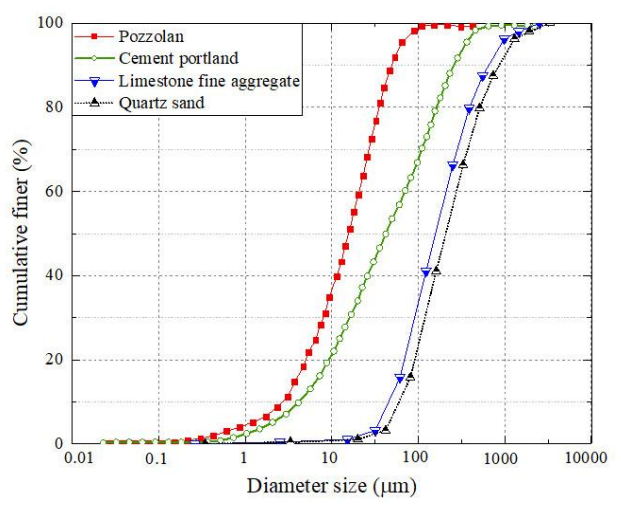

Fig. 1. Particle size distribution of PC, PU, LFA and QS

\subsection{Calculation of the compositions}

In this experimental program, the compositions of Fine-Grained Concrete (FGC) were designed by the method of absolute volume and mix-1 as the control mixture. On the other hand, the different ratios of used materials by mass in the preparation of mixes FGC are presented in Table 4. In this case of the work, the weight of QS was replaced with $30 \%$, $70 \%$ and $100 \%$ by LFA. In addition, the Portland cement was also replaced with $20 \%, 30 \%$ and $40 \%$ by mass of PU. Besides that, according to data from previous studies [2, 10, 14, 15], the ratios of water - binder, fine aggregate - binder and SR5000 - cement were chosen, respectively, of $0.3,1.3$ and 0.02 and kept constant for all test mixtures (volume of air in concrete $3.5 \%$ ). Thus, combined with the absolute volume method, the four of the FGCmixes with varying contents of LFA and PU were made for current study (see Table 4).

Table 4. Ratio of materials and proportions of the FGC.

\begin{tabular}{|c|c|c|c|c|c|c|c|c|c|c|c|}
\hline \multirow{2}{*}{ Mixes } & \multicolumn{4}{|c|}{ Ratios of raw materials } & \multicolumn{5}{|c|}{ Concrete mixture $\left(\mathrm{kg} / \mathrm{m}^{3}\right)$} \\
\cline { 2 - 10 } & $\begin{array}{c}\text { LFA } \\
(\%)\end{array}$ & $\begin{array}{c}\text { QS } \\
(\%)\end{array}$ & $\frac{\mathrm{PU}}{\mathrm{PC}}$ & $\frac{\mathrm{W}}{\mathrm{BI}}$ & $\mathrm{SP}(\%)$ & PC & PU & QS & LFA & SP & W \\
\hline Mix-1 (control) & 0 & 100 & 0 & \multirow{3}{*}{0.3} & & 856 & 0 & 1113 & 0 & 17 & 257 \\
\hline Mix-2 & 30 & 70 & 0.2 & & 695 & 139 & 759 & 325 & 14 & 250 \\
\hline Mix-3 & 70 & 30 & 0.3 & & & 630 & 189 & 319 & 745 & 13 & 246 \\
\hline Mix-4 & 100 & 0 & 0.4 & & & 536 & 268 & 0 & 1045 & 11 & 241 \\
\hline
\end{tabular}

\subsection{Methods}

a). In this investigation, the method of laser granulometry on the device BT-9300Z was used to analyze the chemical and grain compositions of PC, PU, LFA and QS.

b). The slump flow of FGC-mixture was determined by the slump mini-cone with dimension of $70 \mathrm{~mm}$ upper diameter x $80 \mathrm{~mm}$ lower diameter x $40 \mathrm{~mm}$ height (Figure 2). Besides, a dry density of FGC was determined by standard ASTM C 138. 
c). The compressive strength test ( $f_{c s}, \mathrm{MPa}$ ) of HPFC was performed at 1, 3, 7, 14, 28, and 56 days using cubic specimens of $70.7 \times 70.7 \times 70.7 \mathrm{~mm}$ (Figure 3) as stipulated by GOST 10180-2012 Russian (Russian Federation standard).

d). The flexural strength ( $\left.\mathrm{f}_{\mathrm{fs}}, \mathrm{MPa}\right)$ of the HPFC specimens was determined in accordance with ASTM C 78 on the $100 \times 100 \times 400 \mathrm{~mm}$ prismatic specimens (Figure 4) and using the method of third point loading. The flexural strength of HPFC specimens was measured at 28 days. In addition, modulus of elasticity (E, MPa) of the HPFC was was determined on $150 \times 300 \mathrm{~mm}$ cylinder at age 28 -day.

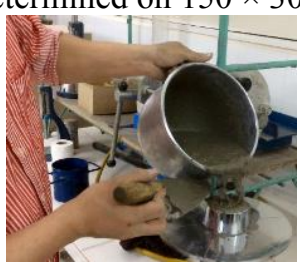

Fig. 2. Determination of the slump-flow of concrete mixture.

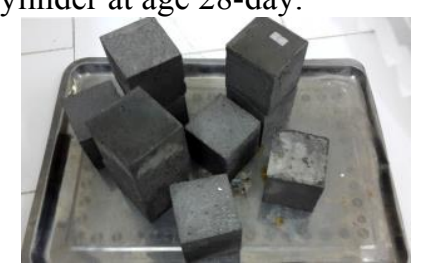

Fig. 3. The test cubic specimens of $70.7 \times 70.7 \times 70.7 \mathrm{~mm}$.

All the test specimens were demoded after 1-day right after casting and subjected to standard maintenance (temperature of $20 \pm 5^{\circ} \mathrm{C}$ and humidity $>90 \%$ ) until the age of design. The test was performed using a computer controlled compression tester "Controls Advantest 9" with a constant loading rate of $2000 \mathrm{~N} / \mathrm{s}$ in order to keep the loading rate to a minimum rate in comparison with the test results of test concrete specimens.

e). Corrosion resistance reinforced in test HPFC specimens. The tests were conducted according by standard NT Build 356 [16]. The considered method is aimed at an accelerated assessment of the degree of protection against corrosion's reinforced in concrete structures, operated under the ground, in water and in other aggressive environments.

The experimental setup and HPFC samples, with which the experiment was conducted, are shown in Figures 5 and 6. The samples had the shape of a cylinder the size of 100x200 $\mathrm{mm}$, in the middle of the sample was installed steel rod $10 \mathrm{~mm}$ in diameter, simulating the valve in Figure 5b.

(a)

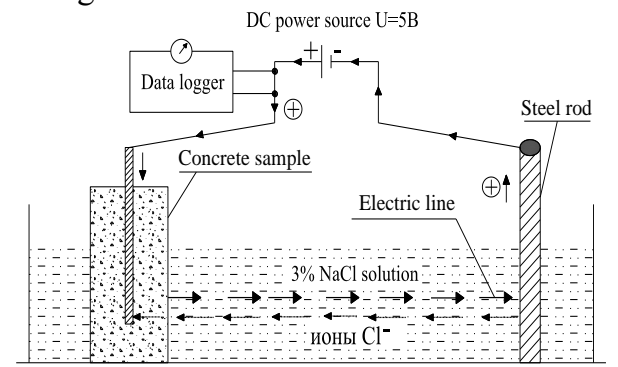

(b)

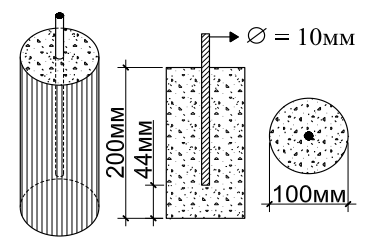

Fig. 5. (a) - Scheme experimental setup and (b) concrete sample for determining the corrosion of HPFC samples accelerated method by standard NT Build 356. 


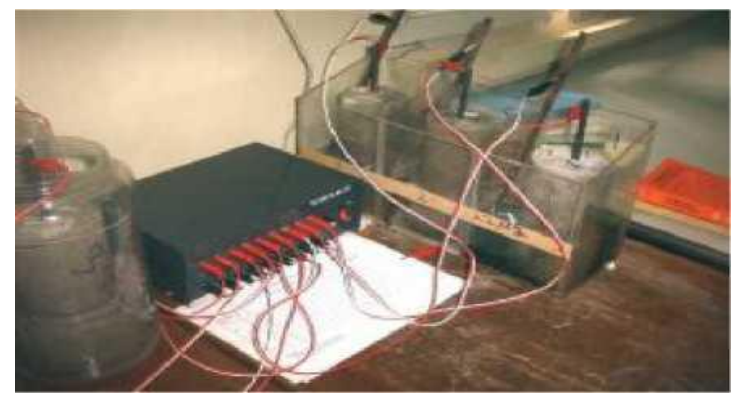

Fig. 6. Samples of concrete, prepared for testing and measuring of amperage through concrete experimental sample.

During the experiment, conducted continuous measurement of the current passing through the HPFC samples. In the initial tests when the concrete layer is still able to protect the steel rod, the recorder records the occurrence of feeble current strength. As the penetration of the chlorine ions from the $3 \% \mathrm{NaCl}$ solution through the concrete cover to the steel rods is an increase in current strength. When the process of destruction of HPFC samples occurs cracking of the protective layer of the concrete, which facilitates access of the electrolyte solution inside the samples to the steel rods, it causes a sharp increase in current strength.

\section{Results and discussion}

\subsection{Properties of Fresh Concrete Mixtures}

In Figures 7(a) and 7(b) were illustrated unit weight tests and the workability, respectively. The properties of concrete mixes are presented in Table 5 and Figure 8. Slump flow loss of the fresh fine-grained concrete for different time periods are given in this Table and Figure 9. Both these four mixtures showed the excellent workability with a slump flow of $18.5 \div$ $23.4 \mathrm{~cm}$ after immediately mixing completion.

(a)

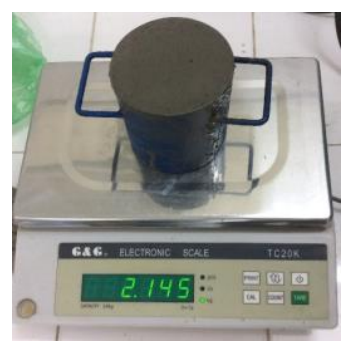

(b)

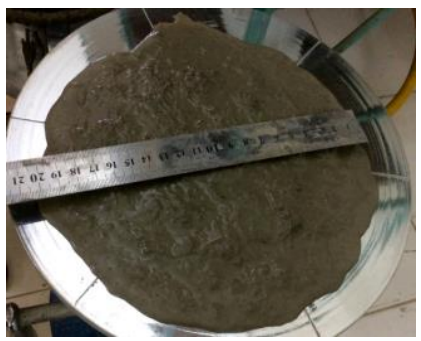

Fig. 7. (a) - Test of unit weight and (b) - Workability of fine-grained concrete mixtures

Table 5. Properties of fresh fine-grained concrete.

\begin{tabular}{|c|c|c|c|c|c|}
\hline \multirow{2}{*}{ Mixes } & \multirow{2}{*}{$\begin{array}{c}\text { Unit weight } \\
\left(\mathrm{kg} / \mathrm{m}^{3}\right)\end{array}$} & $\begin{array}{c}\text { Immediately } \\
\text { after mixing }\end{array}$ & After 30 minutes & After 60 minutes & After 90 minutes \\
\hline Mix-1 & 2202 & 23.4 & 20.8 & 18.3 & 16.2 \\
\hline Mix-2 & 2139 & 20.8 & 18.1 & 15.8 & 14.3 \\
\hline Mix-3 & 2097 & 19.8 & 17.2 & 14.5 & 12.9 \\
\hline Mix-4 & 2053 & 18.5 & 16 & 12.9 & 11.5 \\
\hline
\end{tabular}




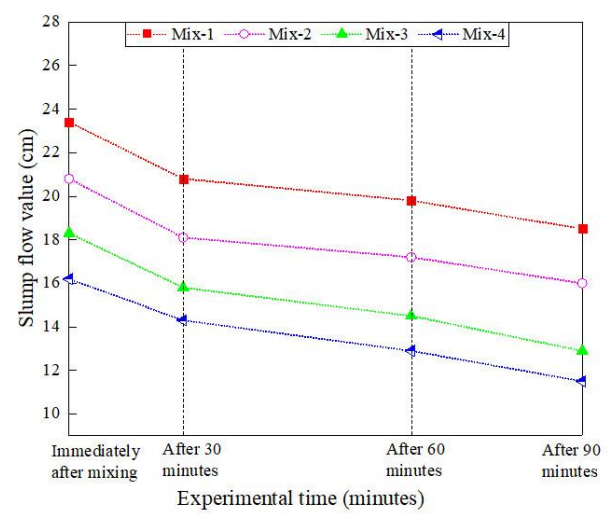

Fig. 8. Slump flow values of fresh fine-grained concrete at different times.

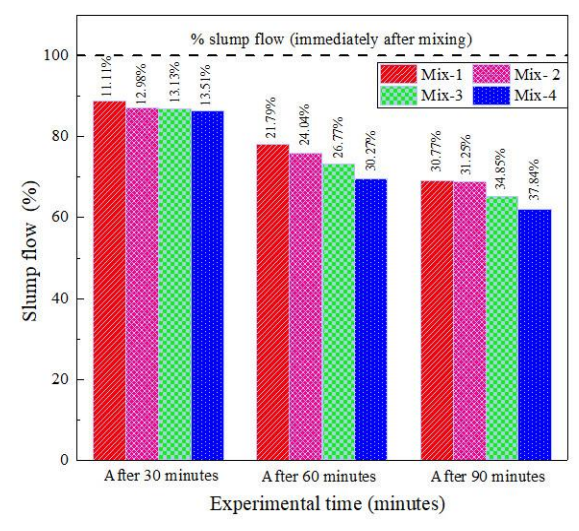

Fig. 9. Workability loss of fresh concrete after 30, 60 and 90 minutes of mixing completion.

From these results indicates that the ratios of LFA in test mixtures increases from $0 \%$ to $100 \%$, its workability was decreased. This is caused by the increase in the fineness of the limestone fine aggregate, as also its specific surface area due to the increase in fines amount and hence more amount of water is required to wet the surface of LFA particles. This result in agreement with a result of published from previous research [17- 19].

\subsection{Mechanical properties of HPFC specimens}

Results of the mechanical properties of fine-grained concrete with $30 \%, 70 \%$, and $100 \%$ of LFA and $20 \%, 30 \%$, and $40 \%$ of PU replacement, respectively, QS and Portland cement are presented in Table 6. As it is known, the most important mechanical properties of concrete include the compressive and flexural strength, as also modulus of elasticity. It is clear that concrete specimens containing LFA and PU at different contents have high mechanical properties than the control specimen.

Table 6. Compressive and flexural strength and elasticity modulus of HPFC at different curing period.

\begin{tabular}{|c|c|c|c|c|c|c|c|c|}
\hline \multirow{2}{*}{ Mixes } & \multicolumn{6}{|c|}{ Compressive strength (MPa) } & \multirow{2}{*}{$\begin{array}{l}\text { Flexural strength } \\
\text { at } 28 \text { days (MPa) }\end{array}$} & \multirow{2}{*}{$\begin{array}{c}\text { Modulus of elasticity } \\
\text { at } 28 \text { days (MPa) }\end{array}$} \\
\hline & 1-day & 3-day & 7-day & 14-day & 28-day & 56-day & & \\
\hline Mix-1 & 10.25 & 22.92 & 36.19 & 53.68 & 58.50 & 60.31 & 4.65 & 13364 \\
\hline Mix-2 & 12.26 & 28.61 & 43.59 & 62.66 & 66.41 & 68.11 & 5.18 & 14844 \\
\hline Mix-3 & 14.87 & 32.72 & 50.56 & 69.90 & 72.87 & 73.36 & 5.47 & 15652 \\
\hline Mix-4 & 16.20 & 35.49 & 56.33 & 73.46 & 76.85 & 77.16 & 5.75 & 15885 \\
\hline
\end{tabular}

(a)

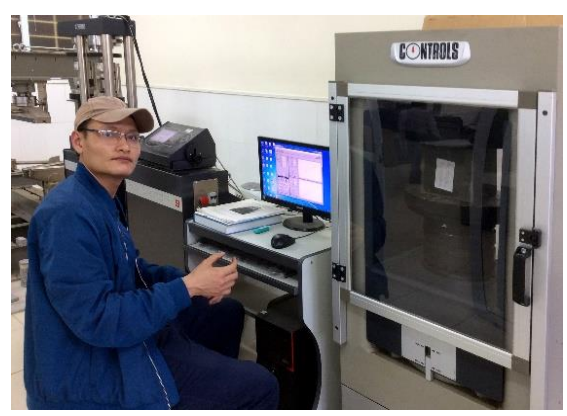

(b)

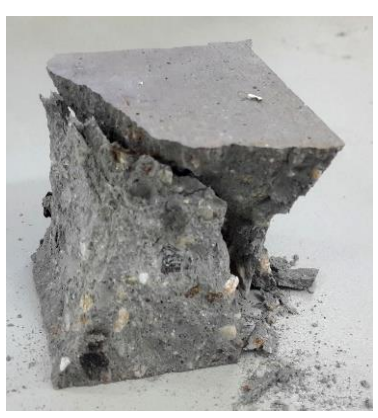

Fig. 10. (a) - Compression test and (b) - Compression failure of HPCF specimen. 
The compression test procedure and compression failure of HPCF specimen were displayed in Figures 10(a) and 10(b), respectively. Figure 11 shows the compressive strength development of HPFC specimens tested of different curing age. Using 100\% LFA replacement QS and 40\% PU as a mineral additive in the test concrete mixture (Mix-4), as it is known that the compressive strength of HPFC increased about $23.87 \%$ in comparison to the control mixture (Mix-1).

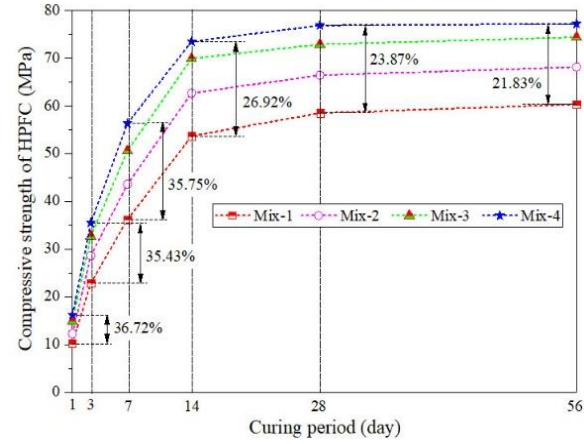

Fig. 11. Compressive strength development of concrete samples.

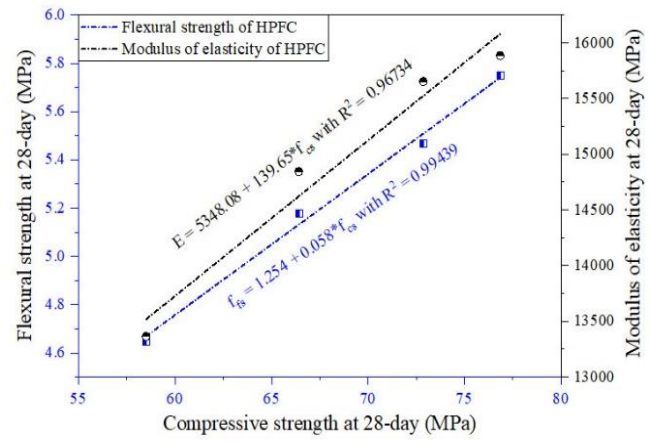

Fig. 12. Correlation between modulus of elasticity, flexural and compressive strength at 28-day.

This increase in compressive and flexural strength is attributed to the increase in surface area of the LFA requiring more cement paste to coat the particles surface of this aggregate. Moreover, this increment in the strength may be due to that the amorphous silica dioxide $\left(\mathrm{SiO}_{2}\right)$ in FLA (of 6.01\%) and in $\mathrm{PU}$ (of $49.8 \%$ ) can react with $\mathrm{Ca}(\mathrm{OH})_{2}$ (calcium hydroxide) in the micro-structure of concrete to form gels secondary calcium-silicatehydrate (C-S-H) and make it more than C-S-H gels and its structurally dense as also the results of published studies [20-24].

Whereas, Figure 12 was presents the fitting relationship between modulus of elasticity and the 28-day compressive-flexural strengths of HPFC specimens, which were shown by two linear regression equations (1) and (2).

$$
\begin{aligned}
& E=5348.08+139.65 * f_{c s} \text { with } R^{2}=0.96734 \\
& f_{f s}=1.254+0.058 * f_{c s} \text { with } R^{2}=0.99439
\end{aligned}
$$

In these equations, the regression coefficients $\left(\mathrm{R}^{2}\right)$ were superior than 0.90 for all finegrained concrete mixtures containing various amounts of LFA and PU represents a very strong negative correlation between the three compared parameters. These relations suggest that with the increase in compressive strength of specimens, the HPFC tested are expected to have high flexural strength and modulus of elasticity.

\subsection{Corrosion of reinforced in HPFC specimen}

In Table 7 and Figure 13 were given the destruction time of the test specimens for four mixtures used for the assessment of the corrosion damage of reinforced in these concretes by standard NT Build 356. It has been observed that for four test mixes with different contents of LFA and PU, the experimental time's destruction of HPFC specimens were 45, 63,60 and 61 days, respectively.

Table 7. The destruction time of HPFC specimens.

\begin{tabular}{|c|c|c|c|c|}
\hline Concrete mixture & Mix-1 & Mix-2 & Mix-3 & Mix-4 \\
\hline Experimental time destruction of specimens (day) & 45 & 63 & 60 & 61 \\
\hline
\end{tabular}




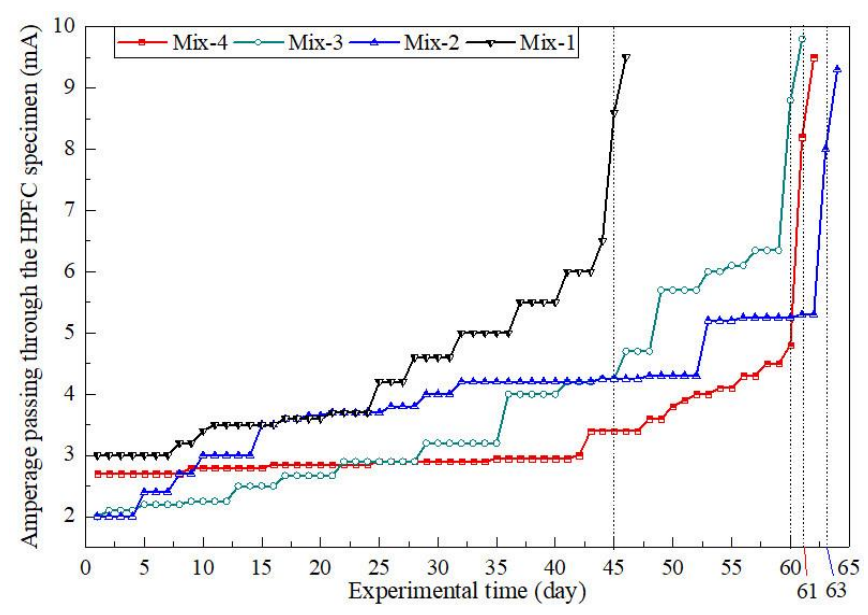

Fig. 13. The destruction time and amount of amperage passing through the HPFC specimens during accelerated tests by standard NT Build 356 .

The damage of concrete specimens as a result of this test were shown in Figure 14. In this case, the mix-2, mix-3 and mix-4 are showed significant higher destruction times than the control mixture (mix-1). It is due to the presence of PU increased the volume of the C$\mathrm{S}-\mathrm{H}$ gel, as well as the density of concrete structure, and therefore reduced the porosity of its structure and enhanced the strength of the structure, also increased destruction time of test specimens. The results of this study, similar to the results presented from previous research [25].

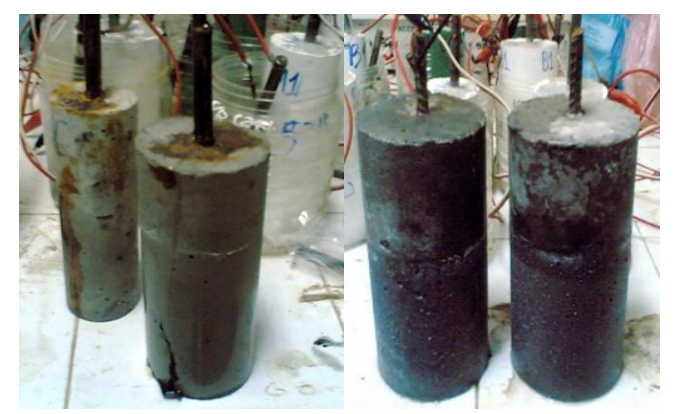

Fig. 14. Corrosion failure of the test HPFC specimens.

\section{Conclusions and future work}

- The unit weight and slump flow values of fresh fine-grained concrete decreased with the increase in limestone fine aggregate and pozzolan contents.

- The average value of slump test of freshly mixed concrete, measured 90 minutes later after the mixing completion, decreased from $30.77 \%$ to $37.84 \%$. Increasing the LFA and PU contents, improved the mechanical properties of concrete.

- Using $100 \%$ of LFA replacement QS and $40 \%$ of PU as a mineral additive in the test concrete mixture, it shows that its compressive strength of HPFC increased about $23.87 \%$ in comparison to the control mixture.

- Application of standard NT Build 356 determined the destruction time of the test specimens 45, 63, 60 and 61 days, respectively. It is due to the presence of PU increased the volume of the C-S-H gel, as well as the density of concrete structure and enhanced the 
strength of the structure, thus increased destruction time of specimens used for the assessment of the corrosion damage of reinforced in the concrete.

- The results of the current study support the use of the waste limestone from the quarries (Vietnam) as a fine aggregate of green concrete in the future.

The authors would like to acknowledge the valuable assistance provided by the fellows of the Department "Technology of Binders and Concretes" at the National Research Moscow State University of Civil Engineering - MGSU (Russian Federation) and the laboratory of Hanoi University of Mining and Geology - HUMG (Vietnam) during this research.

\section{References}

1. T.V. Lam, B.I. Bulgakov, O.V. Aleksandrova, O.A. Larsen, Journal "Bulletin of BSTU. V.G. Shukhov 06, 06-12 (2017) https://doi.org/10.12737/article_5926a059214ca0.89600468

2. T.V. Lam, B.I. Bulgakov, O. Aleksandrova, O. Larsen, N.A. Pham, E3S Web of Conferences 33, 13 (2018), https://doi.org/10.1051/e3sconf/20183302030

3. M.S. Hameed, A.S.S. Sekar, ARPN Journal of Engineering and Applied Sciences 4(4), $83(2009)$

4. E. Yasar, Y. Erdogan, A. Kilic, A. Graubner: Mater. Let. 58, 772 (2004)

5. R.S. Carcano, E.I. Moreno, Constr. Build. Mater. 22, 1125 (2008)

6. A.M. Alhozaimy, Cem. Concr. Comp. 31, 470 (2009)

7. H.S. Yang, K.H. Fang, S.J. Tu, Advanced Materials Research 168, 512 (2010), Doi:10.4028/www.scientific.net/amr.168-170.512

8. B. Menadi, S. Kenai, J. Khatib, A. Aït-Mokhtar, Construction and Building Materials. 23(2), 625 (2009), Doi:10.1016/j.conbuildmat.2008.02.005

9. Z.T. Chang, X.J. Song, R. Munn, M. Marosszeky, Cem. Concr. Res. 35, 1486 (2005)

10. T.P. Huynh, C.L. Hwang, S.H. Ngo, Materials Science Forum. 928, 257 (2018), https://doi.org/10.4028/www.scientific.net/msf.928.257

11. I. Yoshitake, H. Komure, A. Y. Nassif, S. Fukumoto, Constr. Build. Mater. 49, 101 (2013)

12. M. Bederina, Z. Makhloufi, A. Bounoua, T. Bouziani, M. Quéneudec, Construction and Building Materials 47, 146 (2013), Doi:10.1016/j.conbuildmat.2013.05.037

13. M. Schmidt, E. Fehling, C. Geisenhanslüke, Ultra high performance Concrete (UHPC). Proceedings of the International Symposium on Ultra High Performance Concrete (Kassel. Germany. University of Kassel. Germany) (2004)

14. T.V. Lam, B.I. Bulgakov, S. Bazhenova, O. Aleksandrova, N.P. Anh, V.D. Tho, E3S Web of Conferences 33, 02029 (2018), https://doi.org/10.1051/e3sconf/20183302029

15. T.V. Lam, B.I. Bulgakov, O. Aleksandrova, N.P. Anh, Y. Mikhaylovich, IOP Conf. Series: Materials Science and Engineering 365, 032007 (2018), https://doi.org/doi:10.1088/1757-899X/365/3/032007

16. NT Build 356. Concrete, repairing materials and protective coating: Embedded steel method. Chloride permeability (Nordtest Method) (2009)

17. T.V. Lam, N.X. Hung, V.K. Dien, B.I. Bulgakov, O.V. Aleksandrova, MATEC Web of Conferences 251, 01005 (2018), https://doi.org/10.1051/matecconf/201825101005

18. B. Benabed, E.H. Kadri, L. Azzouz, S. Kenai, Cement and Concrete Composites 34(10), 1167 (2012), Doi:10.1016/j.cemconcomp.2012.07.007

19. V.B. Bosiljkov, Cem. Concr. Res. 33, 1279 (2003)

20. O.M. Omar, G.D.A. Elhameed, M.A. Sherif, H.A. Mohamadien, HBRC Journal 8(3), 193 (2012) 
21. M.S. Hameed, A.S.S. Sekar, ARPN Journal of Engineering and Applied Sciences 4(4), 83 (2009)

22. S.C. Kou, C.S. Poon, Construction and Building Materials 23(8), 2877 (2009), Doi:10.1016/j.conbuildmat.2009.02.009

23. N.T. Chuc, T.V. Lam, B.I. Bulgakov, Materials Science Forum 931, 667 (2018), https://doi.org/10.4028/www.scientific.net/MSF.931.667

24. T.V. Lam, N.T. Chuc, N.X. Hung, D.V. Phi, B.I. Bulgakov, S.I. Bazhenova, MATEC Web of Conferences 193, 03024 (2018)

https://doi.org/10.1051/matecconf/201819303024

25. B.I. Bulgakov, T.V. Lam, Journal Industrial and civil construction 05, 26 (2016) 